\title{
Thermal Expansion of Rare-Earth-Doped Ceria Ceramics
}

\author{
Soichiro SAMESHIMA, Manabu KAWAMINAMI and Yoshihiro HIRATA \\ Department of Applied Chemistry and Chemical Engineering, Kagoshima University, 1-21-40, Korimoto, Kagoshima-shi 890-0065
}

\author{
希土類固溶セリアの熱膨張 \\ 鮫島宗一郎 · 河南 学 · 平田好洋 \\ 鹿児島大学工学部応用化学工学科, 890-0065 鹿児島市郡元 1-21-40
}

\begin{abstract}
The thermal expansion of $\mathrm{CeO}_{2}$ and rare-earth-doped ceria $\left(\mathrm{Ce}_{0.8} \mathrm{R}_{0.2} \mathrm{O}_{1.9}, \mathrm{R}: \mathrm{Yb}, \mathrm{Y}, \mathrm{Gd}, \mathrm{Sm}, \mathrm{Nd}\right.$ and $\left.\mathrm{La}\right)$ was measured in the temperature range from 298 to $1473 \mathrm{~K}$. The coefficients of thermal expansion (CTE) were determined by differentiating the thermal expansion expressed by a polynominal equation of temperature with respect to temperature. The CTE $\left(\alpha_{1}\right)$ for $\mathrm{Ce}_{0.8} \mathbf{R}_{0.2} \mathbf{O}_{1.9}$ was in the range from $10 \times 10^{-6}$ to $14 \times 10^{-6} \mathrm{~K}^{-1}$ and increased nonlinearly with increasing temperature. This result was explained by the asymmetric curve of potential energy based on the lattice energy theory. The kinds of dopant gave small effect on the $\alpha_{1}$ of rareearth-doped ceria. On the other hand, the average $\mathrm{CTE}$ for $\mathrm{CeO}_{2}$ and rare-earth-doped ceria $\left(12.0-12.5 \times 10^{-6}\right.$ $\mathrm{K}^{-1}$ ), determined from a linear approximation of thermal expansion with respect to temperature at 298$1273 \mathrm{~K}$, was lower than the $\alpha_{1}$ and close to the previously reported values.
\end{abstract}

[Received March 8, 2002; Accepted May 21, 2002]

Key-words : Rare-earth-doped ceria, Coefficient of thermal expansion, Potential energy, Ionic radius, Lattice energy theory

1. Introduction

Solid oxide fuel cell (SOFC) can generate high-efficiency electric power using $\mathrm{H}_{2}$ and $\mathrm{O}_{2}$ gases without environmental pollution, noise and vibration. The well used solid electrolyte of SOFC is $\mathrm{Y}_{2} \mathrm{O}_{3}$-stabilized $\mathrm{ZrO}_{2}$ (YSZ). The SOFC system with YSZ is operated at about $1000^{\circ} \mathrm{C}$. Reducing the operation temperature is useful in increasing the lifetime and choice of the constituent materials (anode, cathode and interconnector) of SOFC. Rare-earth-doped ceria has a higher oxygen ion conductivity than YSZ and is a candidate electrolyte for the low temperature operation. ${ }^{1)-4)}$ In previous papers, ${ }^{5)-9)}$ we reported the synthesis, sintering and electrical conductivity of rare-earth-doped ceria. In addition to the electrical conductivity, the thermal and mechanical properties of solid electrolyte are important factors to design the structure of SOFC. ${ }^{10)-13)}$ The SOFC is a multilayer device consisting of electrolyte, anode, cathode and interconnector. The coefficients of thermal expansion (CTE) of those constituent materials should be close to prevent exfoliation or cracking during heat-cycle of SOFC. Hayashi et al. reported that (1) CTE of Gd-doped ceria became larger with an increase of Gd content and (2) CTE of ceria became large with the increase of oxygen vacancy. ${ }^{14)}$ In this paper, coefficients of thermal expansion of rare-earth-doped ceria ceramics were measured at $298-1473 \mathrm{~K}$ in air. The lattice energy theory was applied to analyze the effects of temperature and dopant on CTE.

\section{Experimental}

$\mathrm{Ce}\left(\mathrm{NO}_{3}\right)_{3} \cdot 6 \mathrm{H}_{2} \mathrm{O}$ (purity $>98.9$ mass $\%$ ), $\mathrm{R}\left(\mathrm{NO}_{3}\right)_{3} \cdot n \mathrm{H}_{2} \mathrm{O}$ (purity $>99.5$ mass\%, R: Yb, Y, Gd, Sm, Nd or La) and $\mathrm{H}_{2} \mathrm{C}_{2} \mathrm{O}_{4} \cdot 2 \mathrm{H}_{2} \mathrm{O}$ (purity $>99.9$ mass $\%$ ) were used as starting materials. ${ }^{5)}$ The cerium and rare-earth nitrate solutions of $0.20 \mathrm{M}$ were mixed at the molar ratio of $\mathrm{Ce} / \mathrm{R}=4 / 1$. The oxalate coprecipitate was prepared by adding the mixed oxalate solution into a stirred oxalic acid solution of $0.4 \mathrm{M}$ drops by drops. The precipitate produced was vacuumfiltrated, washed with distilled water and decomposed to oxice by calcination at $600^{\circ} \mathrm{C}$ for $1 \mathrm{~h}$ in air. The undoped and rare-earth-doped ceria powders of $41.3 \mathrm{~g}\left(40.9 \mathrm{~cm}^{3}\right)$ were milled with alumina ball $(0.3 \mathrm{~cm}$ diameter $)$ of $344 \mathrm{~g}$ for
$24-36 \mathrm{~h}$ at a rate of 85 r.p.m in polyethylene container of $280 \mathrm{~cm}^{3}$ (5.5 cm diameter, $12 \mathrm{~cm}$ length). The phases produced in heated oxides were identified by X-ray powder diffraction. The lattice parameters of crushed powders of samples sintered at $1600^{\circ} \mathrm{C}$ were measured with X-ray powder diffraction (No.2013, Rigaku Co., Tokyo) using $\mathrm{NaCl}$ as a standard substance (50 mass \%) at a scan speed of $0.5 \%$ $\min$.

The calcined powders were consolidated by uniaxial pressing (49 $\mathrm{MPa}$ ) and subsequent cold isostatic pressing $(294 \mathrm{MPa})$, and sintered at $1600^{\circ} \mathrm{C}$ for $4 \mathrm{~h}$ in air. The bulk density was measured by the Archimedes method using distilled water. Thermal expansion of sintered rectangular sample $\left(5 \times 5 \times 20 \mathrm{~mm}^{3}\right)$ polished with abrasive $\mathrm{SiC}$ paper No. 1200 was measured with TMA (thermomechanical analyzer; Model 8310, Rigaku Co.,Tokyo). The sample was twice heated to $1200^{\circ} \mathrm{C}$ in air and cooled to room temperature at a heating and cooling rate of $10^{\circ} \mathrm{C} / \mathrm{min}$. The coefficient of thermal expansion was measured upon the second heating. The measured thermal expansion data were calibrated by blank test and the reference data of $\alpha$-alumina.

\section{Results and discussion}

All the samples were sintered above $98 \%$ of theoretical density at $1600^{\circ} \mathrm{C}$. No crystalline or amorphous secondary phase in the grain interior or at grain boundaries was observed by transmission electron microscopy.7) Lattice parameter (a) increased linearly with increasing the ionic radius of the doped rare-earth element and was fitted by Eq. (1) for the composition of $\mathrm{Ce}_{1-x} \mathrm{R}_{x} \mathrm{O}_{2-(x / 2)}$,

$$
\begin{aligned}
a= & \frac{4}{\sqrt{3}}\left[x b_{1}+(1-x) b_{2}+(1-0.25 x) b_{3}+0.25 x b_{4}\right] \\
& \times 0.9971
\end{aligned}
$$

where $b_{1}, b_{2}, b_{3}$ and $b_{4}$ are the radii of the cation dopant, cerium ion $(0.097 \mathrm{~nm})$, oxygen ion $(0.138 \mathrm{~nm})$ and the oxygen vacancy, respectively. ${ }^{7), 15)}$ Hong and Virkar ${ }^{15)}$ proposed a value of $0.1164 \mathrm{~nm}$ for $b_{4}$. The correction factor, 0.9971 , was introduced from the ratio of the lattice parameter measured for pure ceria $(0.5411 \mathrm{~nm}$, JCPDS No. 34-394) to the 


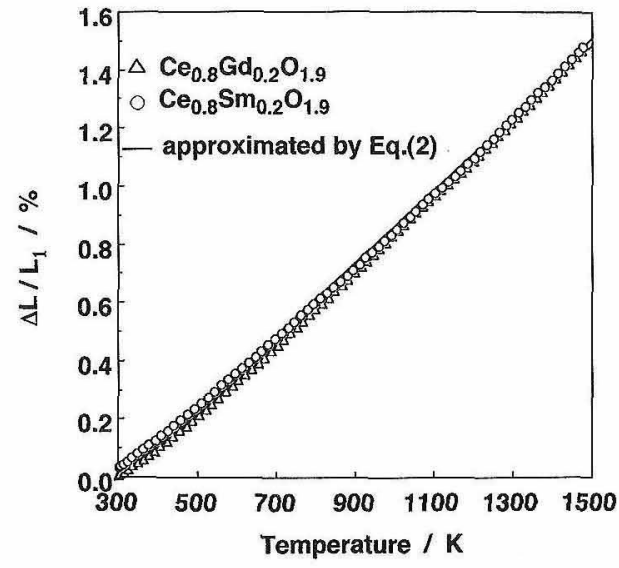

Fig. 1. Thermal expansion of $\mathrm{Ce}_{0.8} \mathrm{Gd}_{0.2} \mathrm{O}_{1.9}$ and $\mathrm{Ce}_{0.8} \mathrm{Sm}_{0.2} \mathrm{O}_{1.9}$.

Table 1. Experimental Constants of Thermal Expansion Expressed by $\Delta L / L_{1}=c_{1}+c_{2} T+c_{3} T^{2}+c_{4} T^{3} \quad\left(L_{1}\right.$; Initial Length at Room Temperature) in the Temperature Range from 298 to 1473 $\mathrm{K}$ and Coefficients of Correlation for $\mathrm{CeO}_{2}$ and Rare-Earth-Doped Ceria

\begin{tabular}{cccccc} 
Sample & $c_{1}$ & $c_{2}$ & $c_{3}$ & $c_{4}$ & $\begin{array}{c}\text { Coefficient of } \\
\text { correlation }\end{array}$ \\
\hline $\mathrm{CeO}_{2}$ & -0.280 & $8.11 \times 10^{-4}$ & $3.53 \times 10^{-7}$ & $-7.89 \times 10^{-11}$ & $>0.9999$ \\
$\mathrm{Ce}_{0.8} \mathrm{Yb}_{0.2} \mathrm{O}_{1.9}$ & -0.249 & $6.76 \times 10^{-4}$ & $5.46 \times 10^{-7}$ & $-1.41 \times 10^{-10}$ & $>0.9999$ \\
$\mathrm{Ce}_{0.8} \mathrm{Y}_{0.2} \mathrm{O}_{1.9}$ & -0.262 & $7.25 \times 10^{-4}$ & $5.21 \times 10^{-7}$ & $-1.44 \times 10^{-10}$ & $>0.9999$ \\
$\mathrm{Ce}_{0.8} \mathrm{Gd}_{0.2} \mathrm{O}_{1.9}$ & -0.274 & $7.73 \times 10^{-4}$ & $4.46 \times 10^{-7}$ & $-1.19 \times 10^{-10}$ & $>0.9999$ \\
$\mathrm{Ce}_{0.8} \mathrm{Sm}_{0.2} \mathrm{O}_{1.9}$ & -0.290 & $1.03 \times 10^{-3}$ & $8.64 \times 10^{-8}$ & $1.86 \times 10^{-11}$ & $>0.9999$ \\
$\mathrm{Ce}_{0.8} \mathrm{Nd}_{0.2} \mathrm{O}_{1.9}$ & -0.296 & $8.86 \times 10^{-4}$ & $2.54 \times 10^{-7}$ & $-3.68 \times 10^{-11}$ & $>0.9999$ \\
$\mathrm{Ce}_{0.8} \mathrm{La}_{0.2} \mathrm{O}_{1.9}$ & -0.272 & $7.78 \times 10^{-4}$ & $3.97 \times 10^{-7}$ & $-9.68 \times 10^{-11}$ & $>0.9999$ \\
\hline
\end{tabular}

calculated value $0.5427 \mathrm{~nm}$ based on the ionic radii.

Figure 1 shows the thermal expansion $\left(\Delta L / L_{1}, L_{1}\right.$ : initial length at room temperature) of $\mathrm{Ce}_{0.8} \mathrm{Gd}_{0.2} \mathrm{O}_{1.9}$ and $\mathrm{Ce}_{0.8} \mathrm{Sm}_{0.2} \mathrm{O}_{1.9}$. The measurement result was approximated by Eq. (2),

$$
\frac{\Delta L}{L_{1}}=c_{1}+c_{2} T+c_{3} T^{2}+c_{4} T^{3}
$$

where $c_{1}, c_{2}, c_{3}$ and $c_{4}$ are the experimental constants, and $T$ is temperature $(\mathrm{K})$. As seen in Fig. 1, the data were well fitted by Eq. (2). Table 1 summarizes the $c$ values in Eq. (2) and the coefficients of correlation for all the samples measured. The coefficients of correlation were greater than 0.9999. The $c_{1}$ and $c_{4}$ were negative values except for the $c_{4}$ of $\mathrm{Ce}_{0.8} \mathrm{Sm}_{0.2} \mathrm{O}_{1.9}$, and the $c_{2}$ and $c_{3}$ resulted in positive values.

The CTE $\left(\alpha_{1}\right)$ based on the sample length at room temperature $\left(L_{1}\right)$ was determined by differentiating Eq. (2) with respect to $T$ (Eq. (3)).

$$
\alpha_{1}=\frac{1}{L_{1}}\left(\frac{\mathrm{d} L}{\mathrm{~d} T}\right)=c_{2}+2 c_{3} T+3 c_{4} T^{2}
$$

Figure 2 shows the $\alpha_{1}$ of $\mathrm{CeO}_{2}, \mathrm{Ce}_{0.8} \mathrm{Yb}_{0.2} \mathrm{O}_{1.9}$, $\mathrm{Ce}_{0.8} \mathrm{Gd}_{0.2} \mathrm{O}_{1.9}$ and $\mathrm{Ce}_{0.8} \mathrm{La}_{0.2} \mathrm{O}_{1.9}$ as a function of temperature. The $\alpha_{1}$ was in the range from $10 \times 10^{-6}$ to $14 \times 10^{-6}$ $\mathrm{K}^{-1}$ and increased nonlinearly with increasing temperature. This result is explained by the potential energy curve based on the lattice energy theory. The potential energy between cation and anion is expressed by Eq. (4),

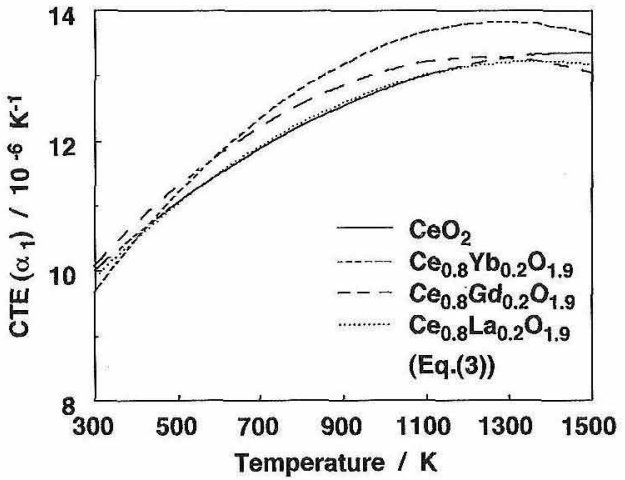

Fig. 2. Coefficients of thermal expansion of $\mathrm{CeO}_{2}, \mathrm{Ce}_{0.8} \mathrm{Yb}_{0.2} \mathrm{O}_{1.9}$, $\mathrm{Ce}_{0.8} \mathrm{Gd}_{0.2} \mathrm{O}_{1.9}$ and $\mathrm{Ce}_{0.8} \mathrm{La}_{0.2} \mathrm{O}_{1.9}$, based on the sample length at room temperature.

$$
E=-\frac{A N_{\mathrm{A}} Z_{1} Z_{2} e^{2}}{4 \pi \varepsilon_{0} r}+\frac{B}{r^{n}}
$$

where $A$ is the Madelung constant 2.51939 for the fluorite structure, $N_{\mathrm{A}}$ the Avogadro constant $6.022 \times 10^{23}, Z_{1}$ the average cation valence $3.8(4(\mathrm{Ce}) \times 0.8+3(\mathrm{R}) \times 0.2), Z_{2}$ the average anion valence including oxygen vacancy $1.9, e$ the charge on the electron $1.602 \times 10^{-19} \mathrm{C}, B$ the repulsion coefficient, $n$ the Born exponent 9.5 (12 for $\mathrm{Ce}^{4+}$ and $\mathrm{R}^{3+}, 7$ for $\left.\mathrm{O}^{2-},(12+7) / 2=9.5\right)$ and $\varepsilon_{0}$ the permittivity of vacuum $8.854 \times 10^{-12} \mathrm{~F} \cdot \mathrm{m}^{-1}$. The $B$ value is given by Eq. (5) from the condition, $\mathrm{d} E / \mathrm{d} r=0$ at $r=r_{0}$ (the equilibrium distance of the $\mathrm{Ce}-\mathrm{O}$ bond at $0 \mathrm{~K}$ ).

$$
B=\frac{A N_{\mathrm{A}} Z_{1} Z_{2} e^{2}}{4 \pi \varepsilon_{0}} \cdot \frac{r_{0}^{n-1}}{n}
$$

The thermal expansion of the cation-O bond was assumed to be expressed by Eq. (2). That is, $r_{0}$ value is given by Eq. (6),

$$
r_{0}=\left(1+c_{1}\right) r_{1}
$$

where $r_{1}$ is the distance of the cation-O bond which was measured as lattice constant at room temperature (Eq. (1)). Figure 3 shows the calculated potential energy curves for $\mathrm{Ce}_{0.8} \mathrm{Yb}_{0.2} \mathrm{O}_{1.9}$ and $\mathrm{Ce}_{0.8} \mathrm{La}_{0.2} \mathrm{O}_{1.9}$. The average distance $(\bar{r})$ of cation- $\mathrm{O}$ bond and the temperature corresponding to the thermal expansion based on $r_{0}$ are plotted in Fig. 3 . The thermal expansion, $\left(\bar{r}-r_{0}\right) / r_{0}$, becomes larger at higher temperature because of the asymmetric curve of potential energy, explaining the results shown in Fig. 2.

Equation (7) and Fig. 4 show the normalized relation between the potential energy $\left(E / E_{0}\right)$ and distance of cation-O bond $\left(r / r_{0}\right)$ for a rare-earth-doped ceria.

$$
\frac{E}{E_{0}}=\frac{r_{0}}{r} \cdot \frac{n+\left(\frac{r_{0}}{r}\right)^{n-1}}{n+1}
$$

The normalized potential energy curve is independent of the dopant. The effect of dopant on CTE is reflected in the corresponding temperature, indicating small influence of dopant. These corresponding temperatures in Figs. 3 and 4 were associated with the thermal expansion coefficient calculated by Eq. (8). The CTE $\left(\alpha_{0}\right)$ based on the sample length at $0 \mathrm{~K}\left(L_{0}\right)$ is expressed by Eq. (8).

$$
\alpha_{0}=\frac{1}{L_{0}}\left(\frac{\mathrm{d} L}{\mathrm{~d} T}\right)=\frac{\alpha_{1}}{1+c_{1}}
$$

Figure 5 shows $\alpha_{0}$ for the rare-earth-doped ceria and undoped ceria. The difference in $\alpha_{0}$ values with the dopant was 


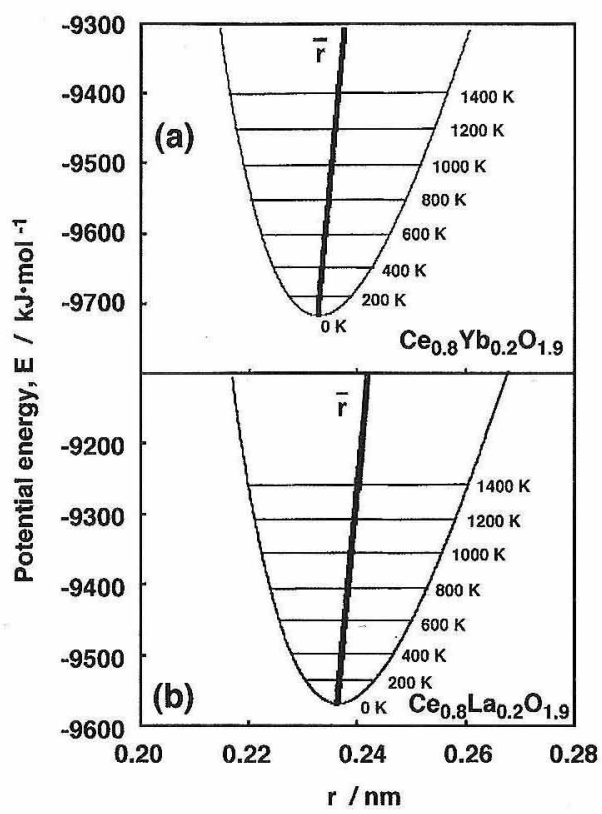

Fig. 3. Calculated potential energy curves for $\mathrm{Ce}_{0.8} \mathrm{Yb}_{0.2} \mathrm{O}_{1.9}$ and $\mathrm{Ce}_{0.8} \mathrm{La}_{0.2} \mathrm{O}_{1.9}$.

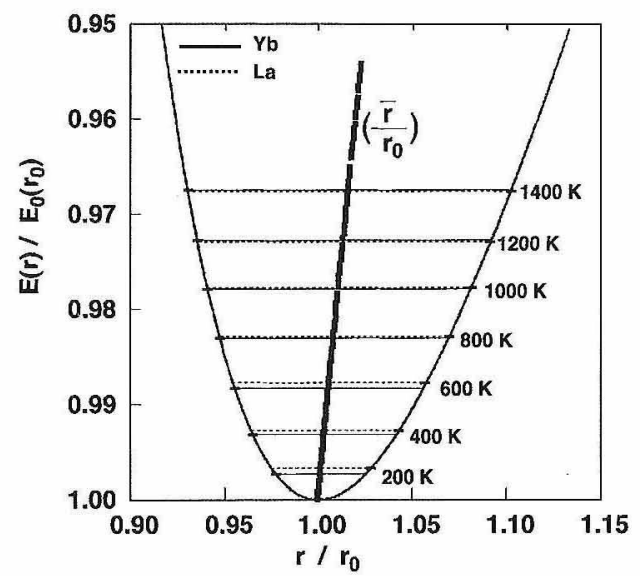

Fig. 4. Normalized relation between potential energy $\left(E / E_{0}\right)$ and distance of cation-O bond $\left(r / r_{0}\right)$ for rare-earth-doped ceria.

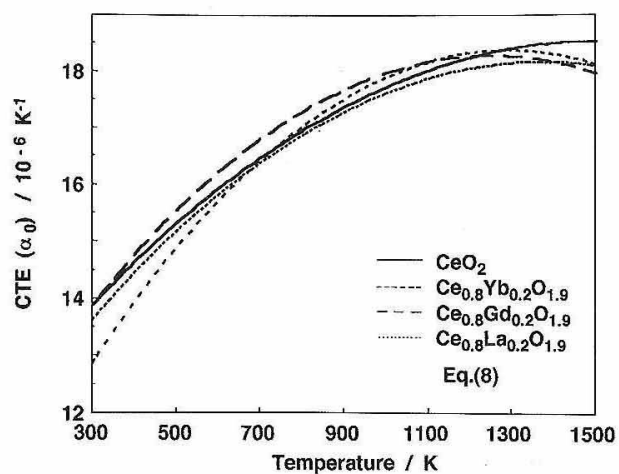

Fig. 5. Coefficients of thermal expansion of $\mathrm{CeO}_{2}, \mathrm{Ce}_{0.8} \mathrm{Yb}_{0.2} \mathrm{O}_{1.9}$, $\mathrm{Ce}_{0.8} \mathrm{Gd}_{0.2} \mathrm{O}_{1.9}$ and $\mathrm{Ce}_{0.8} \mathrm{La}_{0.2} \mathrm{O}_{1.9}$, based on the sample length at $0 \mathrm{~K}$.

less than $0.5 \times 10^{-6} \mathrm{~K}^{-1}$ in the temperature range from 700 to $1500 \mathrm{~K}$, indicating the small influence of dopant. Since the change of sample length with temperature $(\mathrm{d} L / \mathrm{d} T)$ in Eq. (3) is the same value that in Eq. (8), the $\alpha_{0}$ becomes larger than the $\alpha_{1}$ because $L_{0}$ is shorter than $L_{1}$.

Table 2 compares the $\alpha_{1}$ value at $1273 \mathrm{~K}$ with the average $\mathrm{CTE}$ in the temperature range from 298 to $1273 \mathrm{~K}$ for the rare-earth-doped ceria and undoped ceria. The average $\alpha_{1}$ (No. 1) in Table 2 corresponds to $c_{2}$ in Eq. (3) for $c_{3}=c_{4}=0$ when the thermal expansion at 298-1273 K was approximated by a linear relation with respect to temperature using the least-squares method. The average $\alpha_{1}$ (No. 2) was calculated from the two sample lengths at 298 and $1273 \mathrm{~K}$. As seen in Table 2, the difference in CTE with the dopant in ceria was small and the CTE value became smaller in the following order: $\alpha_{1}>$ average $\alpha_{1}$ (No. 1) $\geq$ average $\alpha_{1}$ (No. 2). The measured average $\alpha_{1}$ (No. 2) was compared with the previously reported ones. Our data were very close to the reference data in Table 2 . The average $\alpha_{1}$ (No. 2) for $\mathrm{Ce}_{0.8} \mathrm{Gd}_{0.2} \mathrm{O}_{1.9}$ of $93 \%$ of theoretical density in Ref. 18) was slightly lower than the result in this experiment with sample of $98.3 \%$ of theoretical density. This difference in CTE may come from the influence of porosity.

\section{Conclusions}

The CTE of rare-earth-doped ceria with a composition of $\mathrm{Ce}_{0.8} \mathrm{R}_{0.2} \mathrm{O}_{1.9}$ was measured at $298-1473 \mathrm{~K}$ in air and analyzed by the lattice energy theory. The CTE $\left(\alpha_{1}, 10 \times 10^{-6}-\right.$

Table 2. Coefficients of Thermal Expansion (CTE) of $\mathrm{CeO}_{2}$ and Rare-Earth-Doped Ceria

\begin{tabular}{|c|c|c|c|c|}
\hline \multirow{4}{*}{ Sample } & \multicolumn{4}{|c|}{ CTE $\left(\times 10^{-6} \mathrm{~K}^{-1}\right)$} \\
\hline & \multicolumn{3}{|c|}{ This study } & \multirow{3}{*}{$\begin{array}{l}\text { Reference data } \\
\text { ave. } \alpha_{1}(\text { No. } 2)^{* *} \\
\approx 300-1273 \mathrm{~K}\end{array}$} \\
\hline & $\alpha_{1}$ & ave. $\alpha_{1}(\text { No. } 1)^{*}$ & ave. $\alpha_{1}(\text { No. } 2)^{* *}$ & \\
\hline & at $1273 \mathrm{~K}$ & $298-1273 \mathrm{~K}$ & $298-1273 \mathrm{~K}$ & \\
\hline $\mathrm{CeO}_{2}$ & 13.3 & 12.0 & 11.8 & 11.8 (Ref.16) $^{\# 1}, 12.1 \pm 0.5$ (Ref.17) \\
\hline $\mathrm{Ce}_{0.8} \mathrm{Yb}_{0.2} \mathrm{O}_{1.9}$ & 13.8 & 12.5 & 12.3 & - \\
\hline $\mathrm{Ce}_{0.8} \mathrm{Y}_{0.2} \mathrm{O}_{1.9}$ & 13.5 & 12.5 & 12.3 & - \\
\hline $\mathrm{Ce}_{0.8} \mathrm{Gd}_{0.2} \mathrm{O}_{1.9}$ & 13.3 & 12.3 & 12.1 & 11.59 (Ref.18),11.8 (Ref.19) \\
\hline $\mathrm{Ce}_{0.8} \mathrm{Sm}_{0.2} \mathrm{O}_{1.9}$ & 13.4 & 12.0 & 12.2 & $12.2(\text { Ref. } 20)^{* 2}$ \\
\hline $\mathrm{Ce}_{0.8} \mathrm{Nd}_{0.2} \mathrm{O}_{1.9}$ & 13.5 & 12.1 & 11.9 & - \\
\hline $\mathrm{Ce}_{0.8} \mathrm{La}_{0.2} \mathrm{O}_{1,9}$ & 13.2 & 12.0 & 11.9 & $\longrightarrow$ \\
\hline
\end{tabular}

*: determined by a linear approximation of thermal expansion with respect to temperature in the rage from 298 to $1273 \mathrm{~K}$.

**: determined from the two sample lengths at 298 and $1273 \mathrm{~K}$.

\#1: 298 - $1073 \mathrm{~K}$, \#2: 293-1223 K 
$14 \times 10^{-6} \mathrm{~K}^{-1}$ ), determined by differentiating the thermal expansion expressed by a polynominal equation of temperature with respect to temperature, became larger at a higher temperature. This result was explained using the asymmetric potential energy curve as a function of distance of cation-O bond. The dopant in ceria provided small effect on CTE. The average CTE (average $\alpha_{1}$ (No. 1)) in the temperature range from 298 to $1273 \mathrm{~K}$, which was determined from a linear approximation of the thermal expansion with respect to temperature using the least-squares method, was lower than the $\alpha_{1}$ and close to the average $\alpha_{1}$ (No. 2) determined from the two sample lengths at 298 and $1273 \mathrm{~K}$. The average $\alpha_{1}$ (No. 2) values in this experiment were very close to the previously reported values.

\section{References}

1) Etsell, T. H. and Flengas, S. N., Chem. Rev., 70, 339-79 (1970).

2) Tuller, H. L. and Nowick, A. S., J. Electrochem. Soc., 122 , 255-59 (1975).

3) Kudo, T. and Obayashi, H., J. Electrochem. Soc., 122, 142-47 (1975).

4) Inaba, H. and Tagawa, H., Solids State Ionics, 83, 1-16 (1996).

5) Higashi, K., Sonoda, K., Ono, H., Sameshima, S. and Hirata, Y., J. Mater. Res., 14, 957-67 (1999).

6) Hirata, Y., Ono, H., Higashi, K., Sonoda, K., Sameshima, S. and Ikuma, Y., Ceram. Trans., 92, 137-48 (1999).
7) Sameshima, S., Ono, H., Higashi, K. and Hirata, Y., J. Ceram. Soc. Japan, 108, 985-88 (2000).

8) Sameshima, S., Ono, H., Higashi, K., Sonoda, K., Hirata, Y. and Ikuma, Y., J. Ceram. Soc. Japan, 108, 1060-66 (2000).

9) Sameshima, S., Higashi, K. and Hirata, Y., J. Ceram. Proc. Res., 1, 27-33 (2000).

10) Sameshima, S., Ichikawa, T., Kawaminami, M. and Hirata, Y., Mater. Chem. and Phys., 61, 31-35 (1999).

11) Minh, N. Q., J. Am. Ceram. Soc., 76, 563-88 (1995).

12) Ftios, C., Nauer, M. and Steel, B. C. H., J. Eur. Ceram. Soc., 12, 267-70 (1993)

13) Kim, N., Kim, B. H. and Lee, D., J. Power Sorce, 90, 139-43 (2000).

14) Hayashi, H., Kanoh, M., Quan, C. J., Inaba, H., Wang, S., Dokiya, M. and Tagawa, H., Solid State Ionics, 132, 227-33 (2000).

15) Hong, S. J. and Virkar, A.V., J. Am. Ceram. Soc., 78, 433-39 (1995).

16) Shuk, P. and Greenblatt, M., Solid State Ionics, 116, 217-23 (1999).

17) Mogensen, M., Sammes, N. M. and Tompsett, G. A., Solid State Ionics, 129, 63-94 (2000).

18) Tompsett, G. A., Sammes, N. M. and Yamamoto, O., J. Am. Ceram. Soc., 80, 3181-86 (1997).

19) Yasuda, I. and Hishinuma, M., Proceedings of Fall Meeting of The Ceramic Society of Japan 1996, Kanazawa (1996) p. 233 [in Japanese].

20) Eguchi, K., Setoguchi, T., Inoue, T. and Arai, H., Solid State Ionics, 52, 165-72 (1992). 